\title{
Genome-wide association of coagulation properties, curd firmness modeling, protein percentage, and acidity in milk from Brown Swiss cows
}

\author{
C. Dadousis, ${ }^{*}$ S. Biffani,† C. Cipolat-Gotet, ${ }^{*}$ E. L. Nicolazzi,ł A. Rossoni,§ E. Santus,§ \\ G. Bittante, ${ }^{*}$ and A. Cecchinato*1 \\ *Department of Agronomy, Food, Natural resources, Animals and Environment (DAFNAE), University of Padova, Viale dell'Università 16, \\ 35020 Legnaro, Italy \\ †Istituto di Biologia e Biotecnologia Agraria (IBBA)-Consiglio Nazionale delle Ricerche (CNR), and \\ ‡Bioinformatics core, Parco Tecnologico Padano, Via Einstein-Loc. Cascina Codazza, 26900 Lodi, Italy \\ §Italian Brown Breeders Association, Loc. Ferlina 204, Bussolengo 37012, Italy
}

\section{ABSTRACT}

Cheese production is increasing in many countries, and a desire toward genetic selection for milk coagulation properties in dairy cattle breeding exists. However, measurements of individual cheesemaking properties are hampered by high costs and labor, whereas traditional single-point milk coagulation properties (MCP) are sometimes criticized. Nevertheless, new modeling of the entire curd firmness and syneresis process $\left(\mathrm{CF}_{\mathrm{t}}\right.$ equation) offers new insight into the cheesemaking process. Moreover, identification of genomic regions regulating milk cheesemaking properties might enhance direct selection of individuals in breeding programs based on cheese ability rather than related milk components. Therefore, the objective of this study was to perform genome-wide association studies to identify genomic regions linked to traditional MCP and new $\mathrm{CF}_{\mathrm{t}}$ parameters, milk acidity $(\mathrm{pH})$, and milk protein percentage. Milk and DNA samples from 1,043 Italian Brown Swiss cows were used. Milk pH and $3 \mathrm{MCP}$ traits were grouped together to represent the MCP set. Four $\mathrm{CF}_{\mathrm{t}}$ equation parameters, 2 derived traits, and protein percentage were considered as the second group of traits $\left(\mathrm{CF}_{\mathrm{t}}\right.$ set $)$. Animals were genotyped with the Illumina SNP50 BeadChip v.2 (Illumina Inc., San Diego, CA). Multitrait animal models were used to estimate variance components. For genome-wide association studies, the genome-wide association using mixed model and regression-genomic control approach was used. In total, 106 significant marker traits associations and 66 single nucleotide polymorphisms were identified on 12 chromosomes $(1,6,9,11,13,15,16,19,20,23$, 26 , and 28). Sharp peaks were detected at 84 to 88 Mbp on Bos taurus autosome (BTA) 6, with a peak at $87.4 \mathrm{Mbp}$ in the region harboring the casein genes.

Received July 7, 2015

Accepted January 20, 2016.

${ }^{1}$ Corresponding author: alessio.cecchinato@unipd.it
Evidence of quantitative trait loci at 82.6 and $88.4 \mathrm{Mbp}$ on the same chromosome was found. All chromosomes but BTA6, BTA11, and BTA28 were associated with only one trait. Only BTA6 was in common between $\mathrm{MCP}$ and $\mathrm{CF}_{\mathrm{t}}$ sets. The new $\mathrm{CF}_{\mathrm{t}}$ traits reinforced the support of MCP signals and provided with additional information on genomic regions that might be involved in regulation of the coagulation process of bovine milk. Key words: genome-wide association study, milk coagulation, curd firmness, dairy cattle

\section{INTRODUCTION}

Milk composition (e.g., fat and protein content) as well as other milk features, such as its acidity $(\mathrm{pH})$, are considered as the base for cheese manufacturing (Walstra et al., 2014). Moreover, cheese processing strongly depends on milk coagulation (clotting of milk by rennet enzymes) as well as the syneresis (shrinkage of the curd with expulsion of whey). Milk coagulation after rennet (or similar coagulation agents) addition is the first step to cheese production. Therefore, milk coagulation properties (MCP), such as rennet coagulation time (RCT, min), time to curd firmness of $20 \mathrm{~mm}\left(\mathbf{k}_{\mathbf{2 0}}\right.$, min), and curd firmness 30 min after rennet addition $\left(\mathbf{a}_{\mathbf{3 0}}, \mathrm{mm}\right)$, are important factors for the description of cheese manufacture. In addition, previous analyses have shown important genetic variation of the MCP traits [for a recent review on MCP genetics see Bittante et al. (2012)]. The heritability of MCP is higher compared with milk yield and similar to other quality traits of milk.

To overcome the problems related to the classical single-point estimates of MCP, such as late and noncoagulating milk samples and low repeatability, it has been proposed to model the curd firmness (CF) as a function of time (Bittante, 2011; Bittante et al., 2013). In this way, $\mathrm{CF}$ values are estimated over a longer time period through a model equation, thus providing extra information of the coagulation and CF processes (which 
also takes into account the phenomenon of syneresis). The wide scale recording of MCP values required for application in breeding programs adds difficulty because the phenotyping of MCP is highly costly and labor demanding. For wide application (at population level) of MCP, infrared spectroscopy has been promising (Cipolat-Gotet et al., 2012; Cecchinato et al., 2013; Chessa et al., 2014). An alternative is the identification of genomic regions regulating the aforementioned traits, linking the desired traits to the genome, which in turn may enhance establishment of marker-assisted selection programs or breeding programs based on whole-genome predictions (Van Eenennaam et al., 2014). For this purpose an experimental trial using daughter design and selective genotyping identified significant associations on chromosomes 2,18 , and 24 using coagulation as a binary trait (i.e., coagulating vs. noncoagulating milk in Finnish Ayrshire cattle; Tyrisevä et al., 2008). Significant associations of $L G B, C S N 2$, and GH1 with RCT have already been reported in candidate gene studies (Bonfatti et al., 2010; Cecchinato et al., 2015b). Moreover, $\mathrm{pH}$ has been associated with GRLF1, LIPE, and $S C D-1$ (Cecchinato et al., 2015b). Cheese yield as well as MCP have also been associated with $L E P, L E P R$, and CSN3 (Glantz et al., 2011). Recently, the CF and syneresis traits have also been tested for genomic associations, resulting in new candidate genes regulating cheesemaking properties of the milk in addition to those identified by the traditional MCP measures (Cecchinato et al., 2015b). Note, however, that all the previous studies were performed on a small number of preselected DNA markers and not on a whole-genome scale. With genome-wide association studies (GWAS), where a large number of SNP distributed along the whole genome are used, new, previously unknown, chromosomal regions associated with traits under investigation can potentially be identified (Schopen et al., 2011).

Exploration of the genetic background and identification of genomic regions affecting milk coagulation and CF might be useful for establishing gene-assisted selection programs or incorporate new knowledge for direct genomic prediction purposes (Glantz et al., 2012). A first attempt on GWAS for MCP traits has been recently presented using a high-density SNP chip but a relatively small number of individuals (379 cows; Gregersen et al., 2015). The aim of the present study was to apply GWAS on Italian Brown Swiss dairy cows genotyped with a 50k SNP chip. Traits investigated were traditional single-point MCP observations in connection to $\mathrm{CF}$ and syneresis traits in an effort to shed more light in the genomic background of cheesemakingrelated traits. Milk acidity and protein percentage were also considered.

\section{MATERIALS AND METHODS}

\section{Field Data}

Milk samples from 1,264 Italian Brown Swiss cows were collected from 85 herds located in Trento Province in the northeast of Italy. With few exceptions, 15 cows from each herd were individually sampled once during evening milking. After collection, milk samples (without preservative) were immediately refrigerated $\left(4^{\circ} \mathrm{C}\right)$. One random subsample was transported to the Milk Quality Laboratory of the Breeders Association of Trento Province (Trento, Italy) for composition analysis. The other subsample was transferred to the CheeseMaking Laboratory of the Department of Agronomy, Food, Natural Resources, Animals and Environment (DAFNAE) of the University of Padova (Legnaro, Padova, Italy) for milk MCP analysis. All samples were processed within $20 \mathrm{~h}$ after collection. Information on cows and herds were provided by the Breeders Association of Trento Province (Italy). Phenotypic data were matched to pedigree information supplied by the Italian Brown Swiss Cattle Breeders Association (ANARB, Verona, Italy).

\section{Analysis of Milk Quality and MCP}

Individual milk subsamples were analyzed for fat, protein, and casein contents using MilkoScan FT6000 (Foss Electric A/S, Hillerød, Denmark). The pH of the subsamples was measured before MCP analysis, using a Crison Basic 25 electrode (Crison, Barcelona, Spain).

Measures of MCP were obtained using the Formagraph instrument (FRM) by Foss Electric A/S according to the procedure described in Cipolat-Gotet et al. (2012). In brief, milk samples (10 $\mathrm{mL})$ were heated to $35^{\circ} \mathrm{C}$ and $200 \mu \mathrm{L}$ of a rennet solution (Hansen Standard 160 , with $80 \pm 5 \%$ chymosin and $20 \pm 5 \%$ pepsin; 160 international milk clotting units/mL; Pacovis Amrein AG, Bern, Switzerland), diluted to $1.6 \%$ (wt/vol) in distilled water, was added at the beginning of analysis. Ten samples were analyzed simultaneously, one sample for each measuring unit of the coagulation meter (pendula), which records the width $(\mathrm{mm})$ of the graph during testing every $15 \mathrm{~s}$. The observation period continued for 90 min after rennet addition. Rennet coagulation time is defined as the time (min) from addition of enzyme to the beginning of coagulation, $\mathrm{k}_{20}(\mathrm{~min})$ is the interval from RCT to the time at which a curd firmness of $20 \mathrm{~mm}$ is attained, and $\mathrm{a}_{30}(\mathrm{~mm})$ is a measure of the extent of curd firmness 30 min after coagulant addition. Samples that did not coagulate within $30 \mathrm{~min}$ were classified as noncoagulating (Ikonen et al., 1999), 
although extension of analysis allowed RCT and $\mathrm{k}_{20}$ values to be detected for all samples.

\section{Modeling the CF of Individual Milk Samples}

Files containing $360 \mathrm{CF}$ values for each milk sample, recorded every $15 \mathrm{~s}$ for $90 \mathrm{~min}$, were retrieved and used to estimate a set of parameters of $\mathrm{CF}$ at time $\mathrm{t}\left(\mathbf{C F}_{\mathbf{t}}\right)$ according to equations and methodology developed by Bittante (2011) and Bittante et al. (2013). Estimated parameters included rennet coagulation time $\left(\mathbf{R C T} \mathbf{T}_{\text {eq }}\right.$, min; estimated from the $\mathrm{CF}_{\mathrm{t}}$ equation); potential asymptotical curd firmness $\left(\mathbf{C F}_{\mathbf{P}}, \mathrm{mm}\right)$, representing the maximum potential curd firmness of a given sample after infinite time in the absence of syneresis; curdfirming rate constant $\left(\mathbf{k}_{\mathrm{CF}}, \% / \mathrm{min}\right)$, which measures the relative velocity of $\mathrm{CF}$; syneresis rate constant $\left(\mathbf{k}_{\mathbf{S R}}, \% / \mathrm{min}\right)$; maximum curd firmness $\left(\mathbf{C F}_{\max }, \mathbf{m m}\right)$; and time to $\mathrm{CF}_{\max }\left(\mathbf{t}_{\max }\right.$, min). A graphical representation of the aforementioned parameters is reported in Figure 1.

\section{Genotyping}

Not all phenotyped animals had blood samples available. In total, 1,152 cows were genotyped using the Illumina BovineSNP50 v.2 BeadChip (Illumina Inc., San Diego, CA). Single nucleotide polymorphisms that fulfilled the following criteria were included in the analysis: (1) call rate $>95 \%,(2)$ minor allele frequency $>0.005$, and (3) no extreme deviation from Hardy-Weinberg

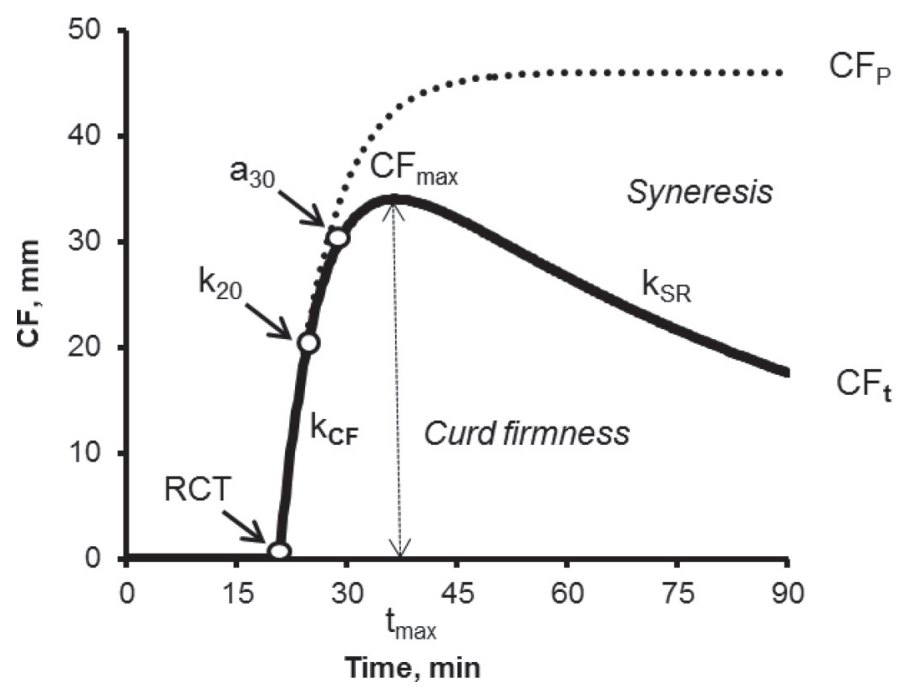

Figure 1. Modeling prolonged observations of curd firmness (CF) at time $\mathrm{t}\left(\mathrm{CF}_{\mathrm{t}}\right)$. Model parameters: $\mathrm{RCT}_{\mathrm{eq}}=$ rennet coagulation time (min) estimated using the $\mathrm{CF}_{\mathrm{t}}$ equation; $\mathrm{CF}_{\mathrm{P}}=$ potential asymptotical curd firmness $(\mathrm{mm}) ; \mathrm{k}_{\mathrm{CF}}=$ curd-firming rate constant $(\% / \mathrm{min}) ; \mathrm{k}_{\mathrm{SR}}$ $=$ syneresis rate constant $(\% / \min ) ; \mathrm{CF}_{\max }=$ maximum curd firmness $(\mathrm{mm}) ; \mathrm{t}_{\max }=$ time to $\mathrm{CF}_{\max }(\mathrm{min})$. equilibrium $(P>0.001$, Bonferroni corrected $)$. After quality control, $37,418 \mathrm{SNP}$, distributed across 29 autosomes and $\mathrm{X}$-chromosome, and 1,043 animals were retained. In total, 109 animals were excluded from the analysis due to low call rate $(<95 \%)$.

\section{Genetic Parameters and Yield Deviation Estimation}

Two multitrait animal models were used to estimate variance components. The first model (MCP set) was used to analyze the following traits: milk $\mathrm{pH}$, RCT (min), $\mathrm{k}_{20}(\mathrm{~min})$, and $\mathrm{a}_{30}(\mathrm{~mm})$. The second model $\left(\mathrm{CF}_{\mathrm{t}}\right.$ set) included milk protein percentage (Prot\%) together with the 4 traits modeling the CF process over time, namely $\mathrm{RCT}_{\mathrm{eq}}(\mathrm{min}), \mathrm{CF}_{\mathrm{P}}(\mathrm{mm}), \mathrm{k}_{\mathrm{CF}}(\% / \mathrm{min}), \mathrm{k}_{\mathrm{SR}}$, $(\% / \mathrm{min})$, and 2 traits estimated from the $\mathrm{CF}$ equation, $\mathrm{CF}_{\max }(\mathrm{mm})$ and $\mathrm{t}_{\max }(\mathrm{min})$. Cows without pedigree and with a lactation longer than 400 DIM were discarded.

According to previous findings (Cecchinato et al., 2013), models for MCP and $\mathrm{CF}_{\mathrm{t}}$ sets accounted for the following fixed effects: DIM (14 classes of DIM defined as 1 class for every $30 \mathrm{~d}$ ), parity ( 1 to 5 or more), and renneting meter sensor of the lactodynamograph (15 levels). The latter effect was fitted only for the $\mathrm{a}_{30}$ trait. Two random effects were included in both models: an uncorrelated random herd effect and an additive genetic effect. In total, 18,905 animals were included in the pedigree.

The basic model to describe the observations written in matrix notation was:

$$
\mathbf{y}=\mathbf{X} \boldsymbol{\beta}+\mathbf{Z}_{\mathbf{h}} \mathbf{h}+\mathbf{Z}_{\mathbf{u}} \mathbf{u}+\mathbf{e}
$$

where $\mathbf{y}$ is a vector of $\mathrm{MCP}$ or $\mathrm{CF}_{\mathrm{t}}$ set traits; $\boldsymbol{\beta}$ is the vector of fixed effects; $\mathbf{h}, \mathbf{u}$, and $\mathbf{e}$ are vectors of random herd, additive genetic, and residual effects, respectively. The $\mathbf{X}$ is the design matrix of fixed effects, $\mathbf{Z}_{\mathbf{h}}$ and $\mathbf{Z}_{\mathbf{u}}$ represent the corresponding incidence matrices linking the phenotypic records to the appropriate random effects. The following normal distributions were assumed for the random effects, $h \sim N\left(0, \mathbf{I} \otimes \mathbf{H}_{0}\right), u \sim N(0, \mathbf{A} \otimes$ $\left.\mathbf{G}_{0}\right)$, and $e \sim N\left(0, \mathbf{I} \otimes \mathbf{R}_{0}\right)$. The (co)variance structure of the random effects was as follows:

$$
\operatorname{Var}\left|\begin{array}{c}
\mathbf{a} \\
\mathbf{h} \\
\mathbf{e}
\end{array}\right|=\left|\begin{array}{ccc}
\mathbf{A} \otimes \mathbf{G}_{0} & 0 & 0 \\
0 & \mathbf{I} \otimes \mathbf{H}_{0} & 0 \\
0 & 0 & \mathbf{I} \otimes \mathbf{R}_{0}
\end{array}\right|,
$$

where $\mathbf{A}$ is the numerator relationship matrix; $\mathbf{G}_{0}$ and $\mathbf{H}_{0}$ are $4 \times 4$ or $7 \times 7$ matrices of polygenic and random herd (co)variances of the traits in models for $\mathrm{MCP}$ set and $\mathrm{CF}_{\mathrm{t}}$ set, respectively; $\mathbf{I}$ is the identity matrix; and $\mathbf{R}_{0}$ is a diagonal matrix of residual variances 
corresponding to each trait. The MCP set model was implemented using the program AIREML90 (Misztal et al., 2002). Program MTJAAM version 3.8 was used to implement the model $\mathrm{CF}_{\mathrm{t}}$ set (Gengler et al., 1997).

Intraherd heritabilities $\left(h_{I H}^{2}\right)$ were defined as

$$
h_{I H}^{2}=\frac{\sigma_{a}^{2}}{\sigma_{a}^{2}+\sigma_{e}^{2}},
$$

where $\sigma_{a}^{2}$ and $\sigma_{e}^{2}$ are additive genetic and residual variances, respectively.

Additive genetic correlations $\left(\boldsymbol{r}_{\boldsymbol{g}}\right)$ were estimated as

$$
r_{g}=\frac{\sigma_{a i, a j}}{\sigma_{a i} \cdot \sigma_{a j}}
$$

where $\sigma_{a i, a j}$ is the additive genetic covariance between trait $i$ and $j$, and $\sigma_{a i}$ and $\sigma_{a j}$ are the additive genetic standard deviations for trait $i$ and $j$, respectively.

The estimated variance and covariance components were used to estimate yield deviations (YD) for the 11 traits. The analyses were carried out using the BLUPF90 program (Misztal et al., 2002). The YD were estimated by adjusting daughter performance for all nongenetic effects (Mrode, 2005):

$$
\mathrm{YD}=\left(\mathbf{Z}_{u}^{\prime} \mathbf{R}_{0}^{-1} \mathbf{Z}_{u}\right)^{-1} \mathbf{Z}_{u}^{\prime} \mathbf{R}_{0}^{-1}\left(\mathbf{y}-\mathbf{X} \hat{\boldsymbol{\beta}}-\mathbf{Z}_{h} \hat{\mathbf{h}}\right)
$$

where $\mathbf{Y D}$ is a vector of yield deviations and $\mathbf{R}_{\mathbf{0}}, \mathbf{y}, \mathbf{X}$, $\boldsymbol{\beta}, \mathbf{Z}_{\mathrm{u}}$, and $\mathbf{h}$ were as defined in equation 1 .

\section{Genome-Wide Associations}

The YD, obtained as previously described, were considered as response variables to perform GWAS using the GenABEL package in R (GenABEL Project Developers, 2013; R Core Team, 2013) adopting the GRAMMAR-GC (genome-wide association using mixed model and regression-genomic control) approach (Amin et al., 2007; Svishcheva et al., 2012). The R package "qqman" was used for graphical representation of GWAS results (Turner, 2014). The GRAMMAR-GC involves a 3-step analysis. In the first step of the procedure, an additive polygenic model is fitted to the adjusted data (YD), using the genomic relationship matrix estimated from SNP data. The reason for including a polygenic term is to obtain residuals that are not biased by the possible population structure, which in our case might be due to the presence of closely related animals. In the second step, associations between residuals and marker genetic polymorphisms are tested in a single-SNP linear regression model. Finally, the genomic control (GC) approach was applied to correct for conservativeness of the GRAMMAR procedure. Genomic control is based on the estimation of the $\zeta$ deflation factor:

$$
\zeta=\frac{\operatorname{Median}\left(T_{1}^{2}, T_{2}^{2}, \ldots T_{N}^{2}\right)}{0.456},
$$

where $T$ is the score-based association test; the deflation factor is the median of the squares of all genomewide computed test statistics divided by the expected median of the test statistic under the null hypothesis of no association, assuming that the number of true associations is very small compared with the number of tests that are actually performed. $P$-values of $\leq 5 \times$ $10^{-5}$ were considered as significant associations (The Wellcome Trust Case Control Consortium, 2007). A search for genes located within $1 \mathrm{Mbp}$ of the most significant SNP was followed (Ensembl Bos taurus UMD3.1; http://www.ensembl.org/index.html).

\section{RESULTS}

\section{Descriptive Statistics}

Descriptive statistics for $\mathrm{MCP}$ and $\mathrm{CF}_{\mathrm{t}}$ set traits are presented in Table 1. Traditional RCT from FRM had an average of 20.19 versus 19.74 min from $\mathrm{RCT}_{\mathrm{eq}}$ estimated modeling the CF process over time. As expected, the latter presented a lower standard deviation (4.34 vs. 6.54) than RCT from FRM because it was estimated using individual equations. The average $\mathrm{k}_{20}$ was $5.72 \mathrm{~min}( \pm 3.67)$, and $\mathrm{a}_{30}$ was $29.19 \mathrm{~mm}( \pm 10.92)$.

The $\mathrm{k}_{\mathrm{SR}}$ had values much lower than $\mathrm{k}_{\mathrm{CF}}$ (average 1.39 vs. $12.45 \% / \mathrm{min}$, respectively), but its coefficient of variation was high $(\sim 40 \%)$. The extension of the observation period to $90 \mathrm{~min}$ permitted us to identify the $\mathrm{CF}_{\max }$ and the $\mathrm{t}_{\max }$ after addition of rennet to milk. On average, $\mathrm{CF}_{\max }$ was $37.05 \mathrm{~mm}$, with a coefficient of variation of $19.4 \%$. The $t_{\max }$ was achieved, on average, at $40.68 \mathrm{~min}$, being almost twice the RCT value.

\section{Genetic Parameters}

Table 2 shows the variance components estimates and the heritabilities for the 2 blocks of considered traits, namely $\mathrm{MCP}$ and $\mathrm{CF}_{\mathrm{t}}$ set. The $3 \mathrm{MCP}$ properties were moderately heritable, with $h_{I H}^{2}$ ranging between 0.15 and 0.27 . For the traits of the $\mathrm{CF}_{\mathrm{t}}$ set heritabilities were again moderate (ranged between 0.21 and 0.26), except for $\mathrm{CF}_{\mathrm{P}}$ and $\mathrm{k}_{\mathrm{SR}}$, which had low $h_{I H}^{2}$ (0.06).

The genetic correlations of the traits analyzed within MCP set are presented in Supplementary Table S1 (http://dx.doi.org/10.3168/jds.2015-10078). Genetic 
Table 1. Descriptive statistics of milk coagulation properties (MCP), parameters of curd firmness modeling on time $\mathrm{t}\left(\mathrm{CF}_{\mathrm{t}}\right)$, milk $\mathrm{pH}$, and protein

\begin{tabular}{|c|c|c|c|c|c|}
\hline Trait $^{1}$ & Mean & $\mathrm{SD}$ & $\mathrm{P} 1$ & P99 & $\mathrm{CV}, \%$ \\
\hline \multicolumn{6}{|l|}{$\overline{\mathrm{MCP}}$} \\
\hline $\mathrm{RCT}, \min$ & 20.19 & 6.54 & 10.30 & 41.00 & 32.4 \\
\hline $\mathrm{k}_{20}, \min$ & 5.72 & 3.67 & 2.00 & 19.42 & 64.2 \\
\hline $\mathrm{a}_{30}, \mathrm{~mm}$ & 29.19 & 10.92 & 0.81 & 50.24 & 37.4 \\
\hline \multicolumn{6}{|l|}{$\mathrm{CF}_{\mathrm{t}}$} \\
\hline $\mathrm{RCT}_{\text {eq }}, \min$ & 19.74 & 4.34 & 15.00 & 28.50 & 40.5 \\
\hline $\mathrm{CF}_{\mathrm{P}}, \mathrm{mm}$ & 54.24 & 13.84 & 26.03 & 96.94 & 25.5 \\
\hline $\mathrm{k}_{\mathrm{CF}}, \% / \min$ & 12.45 & 5.69 & 2.36 & 28.71 & 45.7 \\
\hline $\mathrm{k}_{\mathrm{SR}}, \% / \min$ & 1.39 & 0.56 & 0.15 & 2.85 & 40.5 \\
\hline $\mathrm{CF}_{\max }, \mathrm{mm}$ & 37.05 & 7.17 & 19.40 & 53.67 & 19.4 \\
\hline $\mathrm{t}_{\max }, \min$ & 40.68 & 10.43 & 23.27 & 72.96 & 25.7 \\
\hline Milk pH & 6.64 & 0.08 & 6.42 & 6.84 & 1.2 \\
\hline Protein, \% & 3.72 & 0.41 & 2.91 & 4.71 & 11.1 \\
\hline
\end{tabular}

${ }^{1} \mathrm{P} 1=1$ st percentile; $\mathrm{P} 99=99$ th percentile; $\mathrm{RCT}=$ rennet coagulation time $(\mathrm{min})$ of samples coagulating within $45 \mathrm{~min}$ from enzyme addition; $\mathrm{k}_{20}=$ curd-firming time ( $\mathrm{min}$ ) of samples reaching $20 \mathrm{~mm}$ of firmness within $45 \mathrm{~min}$ from enzyme addition; $\mathrm{a}_{30}=$ curd firmness $(\mathrm{mm})$ at $30 \mathrm{~min}$ after enzyme addition; $\mathrm{RCT}_{\mathrm{eq}}=$ rennet coagulation time (min) estimated using the $\mathrm{CF}_{\mathrm{t}}$ equation; $\mathrm{CF}_{\mathrm{P}}=$ potential asymptotical curd firmness $(\mathrm{mm}) ; \mathrm{k}_{\mathrm{CF}}=$ curd-firming rate constant $(\% / \mathrm{min}) ; \mathrm{k}_{\mathrm{SR}}=$ syneresis rate constant $(\% / \mathrm{min}) ; \mathrm{CF}_{\max }=\operatorname{maximum}$ curd firmness $(\mathrm{mm}) ; \mathrm{t}_{\max }=$ time to $\mathrm{CF}_{\max }(\min )$.

correlations among milk $\mathrm{pH}, \mathrm{RCT}$, and $\mathrm{k}_{20}$ were positive (unfavorable), ranging between 0.36 and 0.65 . On the contrary, $\mathrm{a}_{30}$ was negatively correlated with milk $\mathrm{pH}$, $\mathrm{RCT}$, and $\mathrm{k}_{20}(-0.48,-0.88$, and -0.93 , respectively).

Genetic correlations of the $\mathrm{CF}_{\mathrm{t}}$ set traits are summarized in Supplementary Table S2 (http://dx.doi. org/10.3168/jds.2015-10078). The percentage of milk protein was almost uncorrelated with half of the $\mathrm{CF}_{t}$ traits $\left(\mathrm{RCT}_{\mathrm{eq}}, \mathrm{k}_{\mathrm{CF}}\right.$, and $\left.\mathrm{t}_{\max }\right)$ and moderately correlated with the rest. Also, $\mathrm{RCT}_{\mathrm{eq}}$, apart from Prot\%, was uncorrelated with $\mathrm{k}_{\mathrm{SR}}$ and $\mathrm{CF}_{\max }$. The highest positive $\mathrm{r}_{\mathrm{g}}$

Table 2. Estimates of additive genetic variances $\left(\sigma_{a}^{2}\right)$, and intraherd heritabilities $\left(h_{I H}^{2}\right)$ for milk coagulation properties (MCP), parameters of curd firmness modeling on time $\mathrm{t}\left(\mathrm{CF}_{\mathrm{t}}\right)$, milk $\mathrm{pH}$, and protein

\begin{tabular}{lrc}
\hline Trait $^{1}$ & $\sigma_{a}^{2}$ & $h_{I H}^{2}$ \\
\hline $\mathrm{MCP}$ & $10.40(0.50)$ & $0.27(0.01)$ \\
$\mathrm{RCT}, \min$ & $2.34(0.12)$ & $0.15(0.01)$ \\
$\mathrm{k}_{20}, \min$ & $40.16(2.01)$ & $0.17(0.01)$ \\
$\mathrm{a}_{30}, \mathrm{~mm}$ & & \\
$\mathrm{CF}_{\mathrm{t}}$ & $3.84(0.62)$ & $0.26(0.03)$ \\
$\mathrm{RCT}_{\mathrm{eq}}, \min$ & $9.43(0.20)$ & $0.06(0.01)$ \\
$\mathrm{CF}_{\mathrm{P}}, \mathrm{mm}$ & $5.88(0.98)$ & $0.24(0.03)$ \\
$\mathrm{k}_{\mathrm{CF}}, \% / \mathrm{min}$ & $0.02(0.00)$ & $0.06(0.01)$ \\
$\mathrm{k}_{\mathrm{SR}}, \% / \mathrm{min}$ & $6.96(1.31)$ & $0.21(0.03)$ \\
$\mathrm{CF}_{\max }, \mathrm{mm}$ & $14.76(2.56)$ & $0.22(0.03)$ \\
$\mathrm{t}_{\max }, \min$ & $0.002(0.00)$ & $0.45(0.02)$ \\
$\mathrm{pH}$ & $0.02(0.04)$ & $0.24(0.05)$ \\
$\mathrm{Protein}, \%$ &
\end{tabular}

${ }^{1} \mathrm{RCT}=$ rennet coagulation time $(\mathrm{min})$ of samples coagulating within 45 min from enzyme addition; $\mathrm{k}_{20}=$ curd-firming time ( $\mathrm{min}$ ) of samples reaching $20 \mathrm{~mm}$ of firmness within 45 min from enzyme addition; $\mathrm{a}_{30}=$ curd firmness $(\mathrm{mm})$ at 30 min after enzyme addition; $\mathrm{RCT}_{\mathrm{eq}}=$ rennet coagulation time (min) estimated using the $\mathrm{CF}_{\mathrm{t}}$ equation; $\mathrm{CF}_{\mathrm{P}}$ $=$ potential asymptotical curd firmness $(\mathrm{mm}) ; \mathrm{k}_{\mathrm{CF}}=$ curd-firming rate constant $(\% / \mathrm{min}) ; \mathrm{k}_{\mathrm{SR}}=$ syneresis rate constant $(\% / \min ) ; \mathrm{CF}_{\max }=$ maximum curd firmness $(\mathrm{mm}) ; \mathrm{t}_{\max }=$ time to $\mathrm{CF}_{\max }(\mathrm{min})$.
(0.87) was found between $\mathrm{RCT}_{\text {eq }}$ and $\mathrm{t}_{\max }$, whereas the highest negative $r_{g}$ was between $t_{\max }$ and $k_{C F}(-0.87)$. The rest of the genetic correlations among the traits were moderate, ranging between $\sim 0.20$ to 0.79 in absolute values.

\section{Results of the Genome-Wide Associations}

A total of 106 significant marker trait associations (66 significant SNP) were detected (Table 3, Supplementary Table S3; http://dx.doi.org/10.3168/jds.201510078). From those 106 cases, 81 significant marker trait associations were identified on BTA chromosome $6(76 \%)$, whereas 46 cases were unique (i.e., SNP that were found to be significantly associated with only one trait). From those 46 cases, 17 belong to $\mathrm{CF}_{\max }$ and 10 to Prot\%. On BTA6, 25 out of the 46 cases were detected $(54 \%)$. In total, significant associations were spotted on 12 chromosomes $(1,6,9,11,13,15$, 16, 19, 20, 23, 26, and 28). The traits $\mathrm{CF}_{\mathrm{P}}$ and $\mathrm{CF}_{\max }$ showed the maximum number of significant associations (34 and 17, respectively). On the contrary, milk $\mathrm{pH}$ was the only trait without any signal. The most frequently identified region was on BTA 6 between 85.42 to $88.44 \mathrm{Mbp}$. For both sets of traits analyzed, marker Hapmap52348-rs29024684 (87,396,306 bp) showed the strongest association.

On BTA6, signals were distributed across 5 regions (Table 3, Figure 2). At the first (region 6a; $51.7 \mathrm{Mbp}$ ) $\mathrm{k}_{20}$ was linked. In region $6 \mathrm{~b}(64.18 \mathrm{Mbp}), \mathrm{t}_{\max }$ showed one significant association. The trait $\mathrm{CF}_{\mathrm{P}}$ was associated with a genomic region (6c) between 73.6 and 74.6 Mbp. The broader region on BTA6 between 77.52 and 88.44 Mbp (region 6d) showed signals for all but milk 
Table 3. Summary results of the genome-wide association analyses ${ }^{1}$

\begin{tabular}{|c|c|c|c|c|c|c|c|}
\hline BTA & $\begin{array}{l}\text { No. of SNP } \\
\text { (signals) }\end{array}$ & Interval, Mbp & $P$-value (range) & Top SNP & $\begin{array}{l}\text { Top SNP location, } \\
\text { bp }\end{array}$ & $\begin{array}{l}\text { Top SNP } \\
\text { MAF }\end{array}$ & Trait $^{2}$ \\
\hline$\overline{0^{3}}$ & 1 & - & $5.31 \times 10^{-6}$ & BTA-76907-no-rs & 0 & 0.26 & $\mathrm{CF}_{\mathrm{P}}$ \\
\hline 1 & 1 & - & $4.27 \times 10^{-5}$ & ARS-BFGL-NGS-41048 & $9,484,167$ & 0.09 & $\mathrm{RCT}_{\mathrm{eq}}$ \\
\hline $6 a$ & 1 & - & $2.57 \times 10^{-5}$ & BTB-01451336 & $51,669,513$ & 0.12 & $\mathrm{k}_{20}$ \\
\hline $6 \mathrm{~b}$ & 1 & - & $4.65 \times 10^{-5}$ & Hapmap43353-BTA-76584 & $64,179,687$ & 0.05 & $\mathrm{t}_{\max }$ \\
\hline $6 c$ & $4(4)$ & $73.640-74.607$ & $\left(1.96 \times 10^{-5}, 8.14 \times 10^{-6}\right)$ & Hapmap43042-BTA-76779 & $73,688,640$ & 0.20 & $\mathrm{CF}_{\mathrm{P}}$ \\
\hline $6 \mathrm{~d}$ & $36(74)$ & $77.521-88.442$ & $\left(3.89 \times 10^{-5}, 1.62 \times 10^{-17}\right)$ & Hapmap52348-rs29024684 & $87,396,306$ & 0.24 & $\begin{array}{l}\operatorname{Prot} \%, \mathrm{RCT}, \mathrm{k}_{20}, \mathrm{a}_{30}, \\
\mathrm{RCT}_{\mathrm{eq}}, \mathbf{C F}_{\mathrm{P}}, \mathrm{CF}_{\max }, \mathrm{k}_{\mathrm{CF}}, \mathrm{t}_{\max }\end{array}$ \\
\hline $6 e$ & 1 & - & $2.2 \times 10^{-5}$ & Hapmap47844-BTA-115673 & $113,538,490$ & 0.25 & Prot $\%$ P \\
\hline $9 \mathrm{a}$ & 1 & - & $9.04 \times 10^{-6}$ & Hapmap53034-rs29011422 & $69,696,334$ & 0.34 & Prot $\%$ \\
\hline $9 \mathrm{~b}$ & 1 & - & $1.06 \times 10^{-5}$ & ARS-BFGL-NGS-88859 & $83,575,446$ & 0.38 & Prot $\%$ \\
\hline 11 & $6(8)$ & $85.936-88.029$ & $\left(3.47 \times 10^{-5}, 5.72 \times 10^{-6}\right)$ & BTA-110429-no-rs & $87,670,344$ & 0.42 & $\mathbf{R C T}_{\mathrm{eq}}, \mathrm{t}_{\max }$ \\
\hline 13 & 1 & 30.00000 & $1.45 \times 10^{-5}$ & Hapmap31215-BTA-32775 & $47,879,982$ & 0.01 & $\mathrm{RCT}^{\mathrm{eq}} \mathrm{u}_{\max }$ \\
\hline $15 \mathrm{a}$ & $2(2)$ & $14.243-14.272$ & $\left(2.81 \times 10^{-6}, 2.77 \times 10^{-6}\right)$ & ARS-BFGL-NGS-114291 & $14,242,668$ & 0.01 & $\mathrm{RCT}$ \\
\hline $15 \mathrm{~b}$ & 1 & - & $6.76 \times 10^{-6}$ & ARS-BFGL-NGS-68607 & $55,488,319$ & 0.01 & RCT \\
\hline 16 & 1 & - & $2.74 \times 10^{-5}$ & ARS-BFGL-NGS-17574 & $76,311,292$ & 0.29 & $\mathrm{CF}_{\mathrm{P}}$ \\
\hline 19 & $2(2)$ & $2.094-2.271$ & $\left(2.3 \times 10^{-5}, 2.08 \times 10^{-5}\right)$ & Hapmap39832-BTA-46468 & $2,093,500$ & 0.32 & $a_{30}$ \\
\hline 20 & 1 & - & $3.57 \times 10^{-5}$ & ARS-BFGL-NGS-1751 & $17,412,441$ & 0.17 & $\operatorname{Prot} \%$ \\
\hline $23 \mathrm{a}$ & 1 & - & $2.69 \times 10^{-5}$ & Hapmap38418-BTA-57213 & $8,819,178$ & 0.11 & $\mathrm{k}_{\mathrm{SR}}$ \\
\hline $23 \mathrm{~b}$ & 1 & - & $1.75 \times 10^{-6}$ & ARS-BFGL-NGS-99929 & $10,631,079$ & 0.07 & \\
\hline 26 & 1 & - & $4.3 \times 10^{-5}$ & ARS-BFGL-NGS-23064 & $20,365.711$ & 0.47 & $\mathrm{k}_{\mathrm{CF}}$ \\
\hline $28 \mathrm{a}$ & 1 & - & $2.1 \times 10^{-5}$ & ARS-BFGL-NGS-115508 & $33,729,338$ & 0.11 & $\mathrm{t}_{\max }$ \\
\hline $28 \mathrm{~b}$ & 1 & - & $2.64 \times 10^{-5}$ & Hapmap48306-BTA-36540 & $38,449,335$ & 0.13 & Prot $\%$ \\
\hline
\end{tabular}

${ }^{1}$ BTA = Bos taurus autosome chromosome; SNP (signals) = number of the single nucleotide polymorphisms significantly associated with the trait and the total number of significant signals per each genomic region in parentheses; Interval $=$ the region on the chromosome spanned among the significant SNP (in bp); $P$-value (range) $=P$-value of the highest highest significant SNP on the chromosome in base pairs on UMD3.1 (http://www.ensembl.org/index.html); Top SNP MAF = minor allele frequency of the top SNP.

$\stackrel{2}{2} \mathrm{RCT}=$ rennet coagulation time ( $\mathrm{min}$ ) of samples coagulating within 45 min from enzyme addition; $\mathrm{k}_{20}=$ curd-firming time (min) of samples reaching 20 mm of firmness within 45 ㅇ min from enzyme addition; $\mathrm{a}_{30}=$ curd firmness $(\mathrm{mm})$ at $30 \mathrm{~min}$ after enzyme addition; Prot $\%=$ protein percent; $\mathrm{RCT}_{\text {eq }}=$ rennet coagulation time (min) estimated using the curd

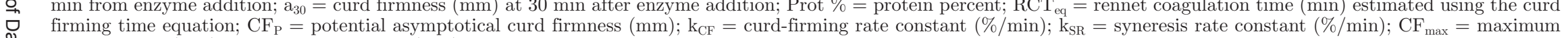
. curd firmness $(\mathrm{mm}) ; \mathrm{t}_{\max }=$ time to $\mathrm{CF}_{\max }(\mathrm{min})$. The trait with the highest $P$-value in each genomic region is bolded.

() ${ }^{3}$ Undefined chromosome and position on the genome. 
$\mathrm{pH}$ and the syneresis rate constant traits, with $P$-values ranging between $3.89 \times 10^{-5}\left(\mathrm{k}_{20}\right)$ and $1.62 \times 10^{-17}$ $\left(\mathrm{CF}_{\mathrm{P}}\right)$; this region also had the strongest signals. At the tail of BTA6 ( 113.5 Mbp), Prot\% showed a signal (region $6 \mathrm{e}$ ). The only trait without any significant association on BTA6 was $\mathrm{k}_{\mathrm{SR}}$.

Apart from BTA6, signals in 11 more chromosomes were detected (Table 3, Figure 3). More precisely, a region on BTA1 at $\sim 9.5 \mathrm{Mbp}$ was associated with $\mathrm{RCT}_{\text {eq }}$. Signals of Prot\% on BTA9 ( 70 and $83.6 \mathrm{Mbp})$, BTA20 ( 17.4 Mbp), and BTA28 (38.45 Mbp) were identified. On BTA28, $\mathrm{t}_{\max }$ was also linked at around $33.8 \mathrm{Mbp}$. On BTA11 the region at $\sim 86$ to $88 \mathrm{Mbp}$ was associated with both $\mathrm{RCT}_{\mathrm{eq}}$ and $\mathrm{t}_{\max }$ with a peak at $87.7 \mathrm{Mbp}$. One region on BTA13 (47.88 Mbp) and 2 regions on BTA15 (14.2 and 55.5 Mbp) were associated with RCT. One SNP on BTA16 ( 76.3 Mbp) was associated with $\mathrm{CF}_{\mathrm{P}}$, whereas a small region on BTA19 $(\sim 2.1-2.3 \mathrm{Mbp})$ was linked to $\mathrm{a}_{30}$. The syneresis rate had only 2 signals, both on BTA 23 at, approximately, 8.8 and $10.6 \mathrm{Mbp}$, whereas $\mathrm{k}_{\mathrm{CF}}$ was associated with BTA26 ( 20.4 Mbp).

With the exception of region $6 \mathrm{~d}$ on BTA6, the rest of the signals were mainly one trait-one genomic region associations with relatively mild strength. As a supporting evidence of the associations identified, the quantile-quantile plots visualizing the distribution of the observed test statistics derived from the GWAS analyses were checked (Supplementary Figure S1; http://dx.doi.org/10.3168/jds.2015-10078). Extreme departures in the tail of the distributions were observed for RCT and $\mathrm{a}_{30}$ from the MCP set and for all the $\mathrm{CF}_{\mathrm{t}}$ set with the exception of $\mathrm{k}_{\mathrm{SR}}$.

Summarizing the GWAS results for the 2 sets of traits, significant SNP for the $3 \mathrm{MCP}$ properties were mainly located on BTA6, with the majority of them mapped within or in close proximity to the casein cluster $(\sim 87.14-87.39 \mathrm{Mbp})$ in a broader area at approximately 84.71 to $88.44 \mathrm{Mbp}$. The regions at 84.89 , 85.42, and 87.39 Mbp on BTA6 were significant for all $3 \mathrm{MCP}$ properties. For the $\mathrm{CF}_{\mathrm{t}}$ traits, sharp peaks were found on BTA6 ( 77.5-87.4 Mbp) mainly associated with $\mathrm{CF}_{\mathrm{P}}$ and $\mathrm{CF}_{\max }$. The majority of common SNP between $\mathrm{CF}_{\mathrm{P}}$ and $\mathrm{CF}_{\max }$ lay in the area at $\sim 84.89$ to 87.40 Mbp. Between MCP and $\mathrm{CF}_{\mathrm{t}}$ set traits, only the BTA6 was in common and, more specifically, the region between 81 and $88.44 \mathrm{Mbp}$.

\section{Conditional Analysis}

Due to the wideness of the region $6 \mathrm{~d}$, a conditional analysis was carried out by fixing in the GWAS model the most significant marker on BTA6 (Hapmap52348rs29024684; 87,396,306 bp) to test if multiple QTL exist on BTA6 (Table 4). Region 6c, as well as a part of region 6d between 77.5 and $81 \mathrm{Mbp}$, were not confirmed in the conditional analysis. Mild signals remained at 81.6 to 84.7 Mbp (for $\mathrm{k}_{20}$, Prot\%, $\mathrm{CF}_{\mathrm{P}}$, and $\mathrm{k}_{\mathrm{CF}}$ ), at 87.15 to 88.8 Mbp (for $\mathrm{RCT}_{\text {eq }}, \operatorname{Prot} \%, \mathrm{CF}_{\max }$, and $\mathrm{k}_{\mathrm{CF}}$ ), as well as region 6e. Region 6a was replaced with a weak signal at $51.7 \mathrm{Mbp}$ (for $\mathrm{k}_{20}$ ), whereas another weak association at $64.18 \mathrm{Mbp}$ (for $\mathrm{t}_{\max }$ ) was detected replacing region 6b. Concerning the rest of the chromosomes, on BTA1, $\mathrm{a}_{30}$ was linked to a region at $29.7 \mathrm{Mbp}$, whereas milk $\mathrm{pH}$ was associated with BTA8 (113.25 Mbp). On BTA11, although the general region of the signals was the same, the peak was detected at $86.8 \mathrm{Mbp}$. On BTA13, the association of RCT (at $47.9 \mathrm{Mbp}$ ) was replaced with a link between $\mathrm{k}_{20}$ and a region at $57.2 \mathrm{Mbp}$. No change on the rest of the results was observed, except marginal changes of the $P$-values and absence of signal on BTA16. It should be mentioned that all the associations in the conditional analysis were weak, with the majority of them around the threshold.

\section{DISCUSSION}

\section{Genetic Parameters}

The majority of the traits analyzed in our study showed moderate heritabilities, which is favorable for breeding purposes. In general, the $\mathrm{CF}_{\mathrm{t}}$ set traits tended to have slightly higher $h_{I H}^{2}$ compared with the MCP set, except $\mathrm{CF}_{\mathrm{P}}$ and $\mathrm{k}_{\mathrm{SR}}$, which showed very low values. Genetic parameters reported here might slightly differ compared with a recently published work based on the same data (Cecchinato et al., 2015b). This might have occurred because of different editing of the data as well as different approaches for variance component estimations; however, both relied on the range of heritability values of MCP reviewed by Bittante et al. (2012).

\section{Genomic Regions Associated with MCP and $\mathrm{CF}_{t}$ Traits}

It is well established that milk protein (and more specifically casein), as well as milk fat content, are strongly related to cheese yield and that casein genetic variants are affecting MCP (reviewed by Bittante et al., 2012). Moreover, it is already known that the casein genes are located on BTA6 (reviewed in Caroli et al., 2009), whereas significant associations of milk technological traits have been reported on BTA11 as well (Heck et al., 2009; Bonfatti et al., 2010; Berry et al., 2010).

\section{BTA6}

Recently, a GWAS on rheological properties of milk, including RCT, was carried out using haplotypes re- 
$\operatorname{Prot} \%$

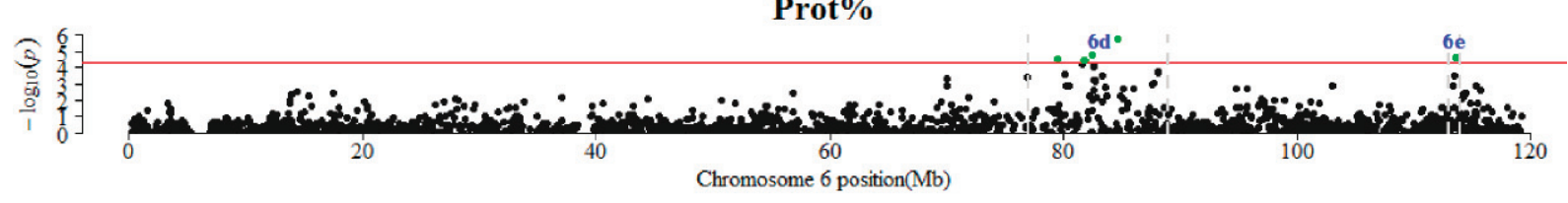

\section{RCT}

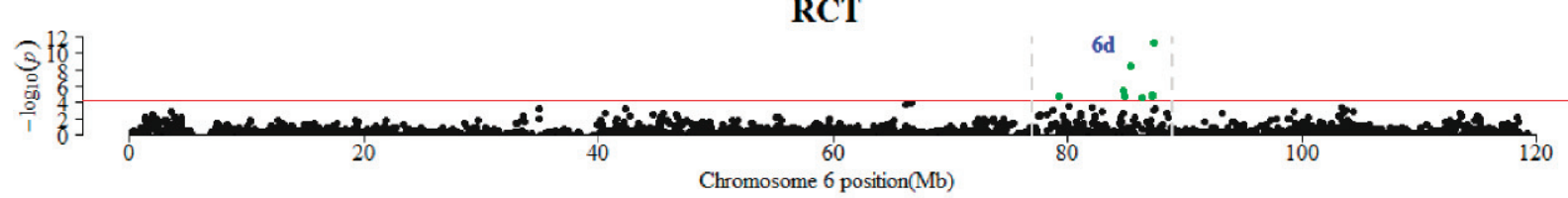

Chromosome 6 position(Mb)

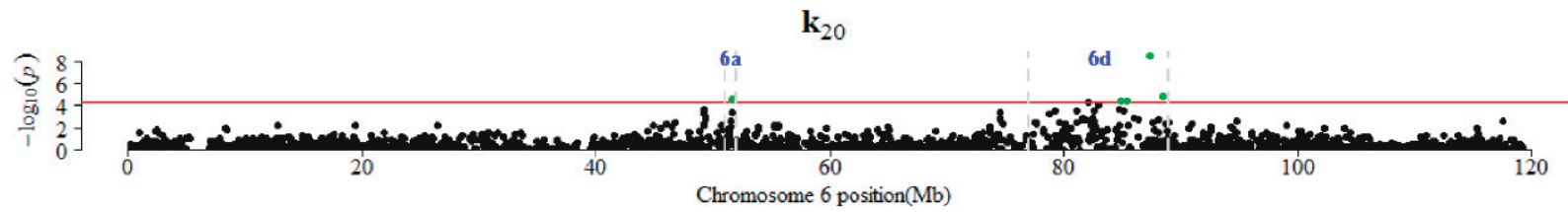

$\mathbf{a}_{30}$

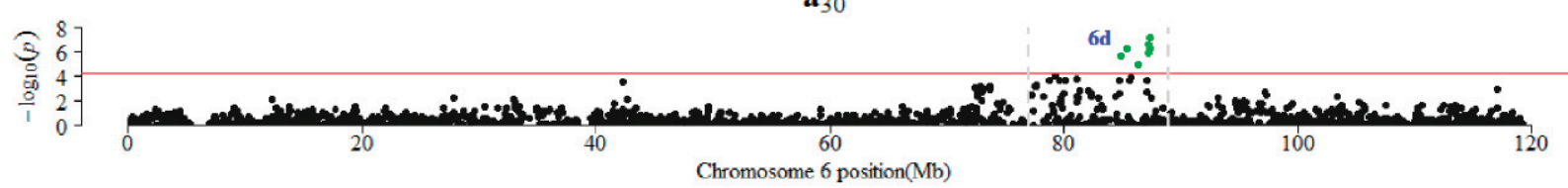

$\mathbf{R C T}_{\text {eq }}$

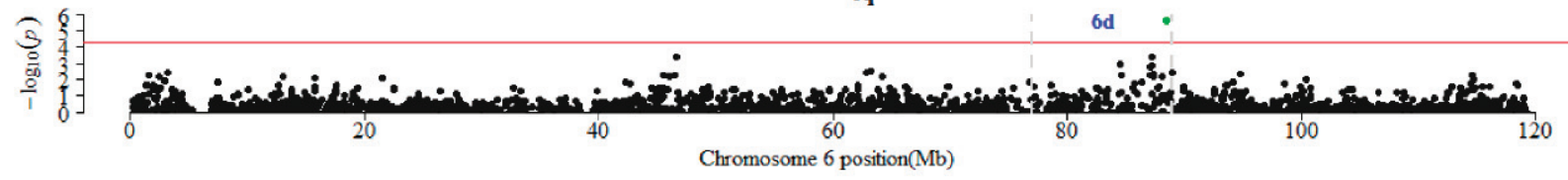

$\mathrm{CF}_{\mathrm{P}}$

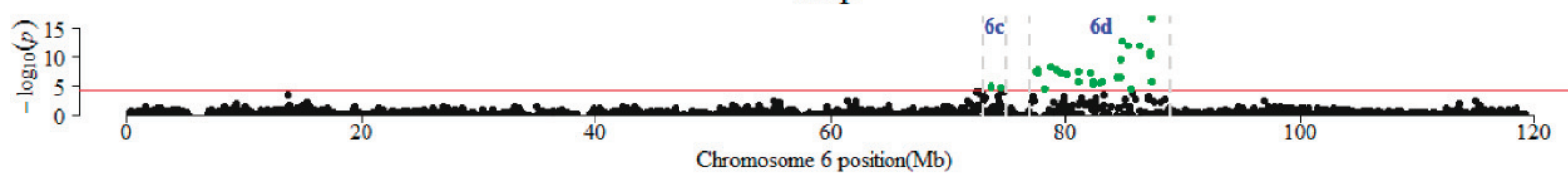

$\mathbf{k}_{\mathrm{CF}}$

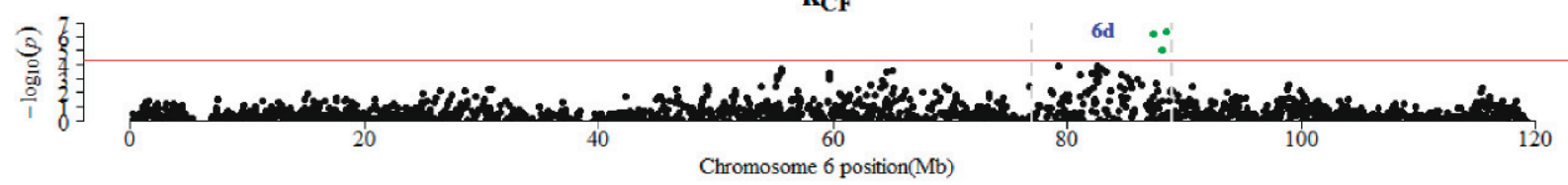

$\mathbf{C F}_{\max }$

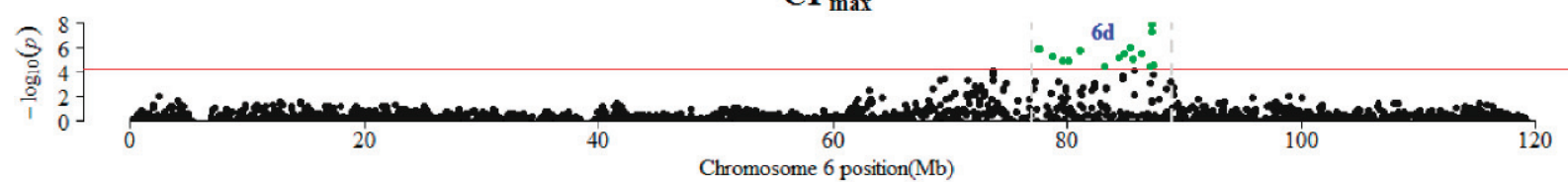

$t_{\max }$

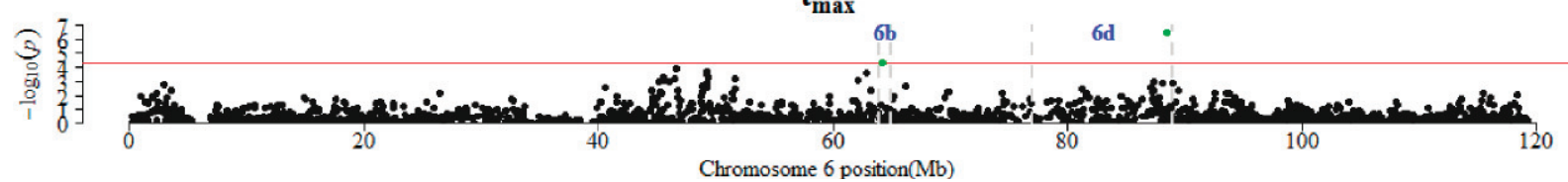

Figure 2. Manhattan plot of $P$-values for the genome-wide association studies (GWAS) on Bos taurus autosome 6 (BTA6). Traits showing significant associations on BTA6 were RCT $=$ rennet coagulation time ( $\mathrm{min}$ ) of samples coagulating within 45 min from enzyme addition; $\mathrm{k}_{20}=$ curd-firming time ( $\mathrm{min}$ ) of samples reaching $20 \mathrm{~mm}$ of firmness within 45 min from enzyme addition; $\mathrm{a}_{30}=\mathrm{curd}$ firmness (mm) at $30 \mathrm{~min}$ after

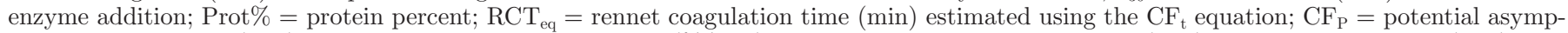
totical curd firmness $(\mathrm{mm}) ; \mathrm{k}_{\mathrm{CF}}=$ curd-firming rate constant $(\% / \mathrm{min}) ; \mathrm{CF}_{\max }=\operatorname{maximum}$ curd firmness $(\operatorname{mm}) ; \mathrm{t}_{\max }=\mathrm{time}$ to $\mathrm{CF}_{\max }(\min )$. The horizontal lines indicate a $-\log 10\left(P\right.$-values) of 4.30 (corresponding to $P$-value $=5 \times 10^{-5}$ ). Color version available online. 

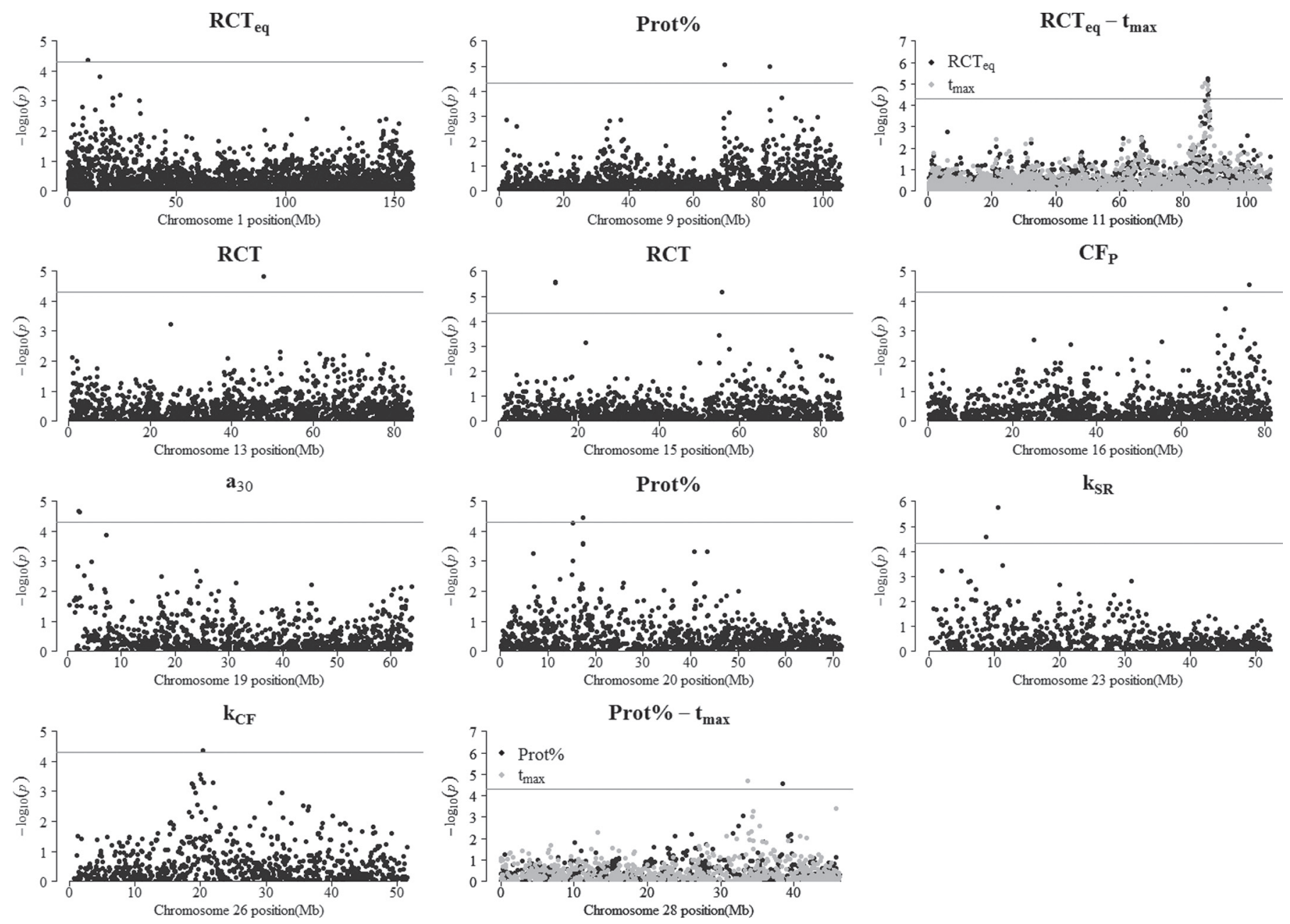

Figure 3. Manhattan plot of $P$-values for the genome-wide association studies (GWAS) on Bos taurus autosomes (BTA) 1, 9, 11, 13, 15, 16, $19,20,23,26$, and $28 . \mathrm{RCT}=$ rennet coagulation time $(\mathrm{min})$ of samples coagulating within 45 min from enzyme addition; $\mathrm{a}_{30}=$ curd firmness $(\mathrm{mm})$ at $30 \mathrm{~min}$ after enzyme addition; Prot $\%=$ protein percent; $\mathrm{RCT}_{\text {eq }}=$ rennet coagulation time $(\min )$ estimated using the $\mathrm{CF}_{\mathrm{t}}$ equation; $\mathrm{CF}_{\mathrm{P}}$ $=$ potential asymptotical curd firmness $(\mathrm{mm}) ; \mathrm{k}_{\mathrm{CF}}=$ curd-firming rate constant $(\% / \mathrm{min}) ; \mathrm{k}_{\mathrm{SR}}=$ syneresis rate constant $(\% / \mathrm{min}) ; \mathrm{t}_{\mathrm{max}}=$ time to maximum curd firmness (min). The horizontal lines indicate a $-\log 10(P$-values $)$ of 4.30 (corresponding to $P$-value $\left.=5 \times 10^{-5}\right)$.

porting high peaks on BTA6 (Gregersen et al., 2015). The importance of the region on BTA6 at roughly 84 to $88 \mathrm{Mbp}$ has also been confirmed in our study, although a broader area, starting from $\sim 82 \mathrm{Mbp}$, has been identified. The region at $88 \mathrm{Mbp}$ has been significantly associated with caseins $(\alpha, \beta, \kappa)$ as well as $\beta$-LG, Prot\%, casein index, and $\alpha-L A$ in another GWAS study (Schopen et al., 2011). In Gregersen et al. (2015), signals around 50.9 and $\sim 60.9 \mathrm{Mbp}$ have been detected, linking to the log-transformed maximum gel strength and $\log (\mathrm{RCT})$, respectively. These regions are in close proximity to regions $6 \mathrm{a}$ and $6 \mathrm{~b}$ in our study (Table 3 ), but they were not confirmed in the conditional analysis (Table 4).

The main region identified in our study was at 84 to $88 \mathrm{Mbp}$ on BTA6 with a peak at $87.4 \mathrm{Mbp}$. This area is gene-dense, including the casein cluster CSN1S1
( 87.14-87.16 Mbp), CSN1S2 ( 87.26-87.28 Mbp), CSN2 ( 87.18-87.19 Mbp), and CSN3 ( 87.39 Mbp). The highest significant SNP identified in our study (Hapmap52348-rs29024684) was located $\sim 18$ kbp upstream of CSN3. Moreover, the marker Hapmap28023BTC-060518 is located within HSTN $(\sim 87,190-87,204$ Mbp), which in turn is mapped between CSN2 and CSN1S2 on BTA6. The HSTN gene is involved in salivary secretion. This SNP was significant for RCT, $\mathrm{k}_{20}$, $\mathrm{a}_{30}, \mathrm{CF}_{\mathrm{P}}$, and $\mathrm{CF}_{\max }$ with $P$-values between $1.32 \times 10^{-5}$ and $1.41 \times 10^{-11}$, and remained significant after adjusting for the Hapmap52348-rs29024684 $\left(P=3.65 \times 10^{-5}\right.$ for $\left.\mathrm{CF}_{\max }\right)$.

Even after adjusting for the effect of the highest significant marker on BTA6, 2 weak signals remained at (1) 81 to $84 \mathrm{Mbp}$ (with a peak at $82.6 \mathrm{Mbp}$ ) and (2) 87 to $89 \mathrm{Mbp}$ (peak at $88.4 \mathrm{Mbp}$ ), indicating the presence 
Table 4. Summary results of the genome-wide association analyses after fixing the marker Hapmap52348-rs29024684 at 87,396,306 bp on BTA6 ${ }^{1}$

\begin{tabular}{|c|c|c|c|c|c|c|c|}
\hline BTA & $\begin{array}{l}\text { No. of SNP } \\
\text { (signals) }\end{array}$ & Interval, Mbp & $P$-value (range) & Top SNP & $\begin{array}{c}\text { Top SNP location, } \\
\text { bp }\end{array}$ & $\begin{array}{l}\text { Top SNP } \\
\text { MAF }\end{array}$ & Trait $^{2}$ \\
\hline 1 & 1 & & $4.46 \times 10^{-5}$ & BTB-02049040 & $29,696,010$ & 0.42 & $\mathrm{a}_{30}$ \\
\hline $6 \mathrm{a}$ & 1 & & $4.99 \times 10^{-5}$ & Hapmap23226-BTA-159656 & $46,599,570$ & 0.24 & $\mathrm{t}_{\max }$ \\
\hline $6 \mathrm{~b}$ & 2 & $69,483-71,421$ & $\left(3.66 \times 10-5,2.67 \times 10^{-5}\right)$ & ARS-BFGL-NGS-20354 & $69,482,838$ & 0.08 & $\mathrm{CF}_{\max }$ \\
\hline 6d_1 & $4(7)$ & $81,652-84,690$ & $\left(4.73 \times 10^{-5}, 5.47 \times 10^{-5}\right)$ & Hapmap27307-BTC-043200 & $82,605,943$ & 0.20 & $\mathrm{k}_{20}, \operatorname{Prot} \%, \mathbf{C F}_{\mathrm{P}}, \mathrm{k}_{\mathrm{CF}}$ \\
\hline 6d_2 & $5(5)$ & $87,153-88,822$ & $\left(4.9 \times 10^{-5}, 9.22 \times 10^{-5}\right)$ & BTA-122637-no-rs & $88,442,145$ & 0.07 & $\mathbf{R C T}_{\mathbf{e q}}, \operatorname{Prot} \%, \mathrm{CF}_{\max }, \mathrm{k}_{\mathrm{CF}}$ \\
\hline $6 \mathrm{e}^{-}$ & 1 & & $1.98 \times 10^{-5}$ & Hapmap47844-BTA-115673 & $113,538,490$ & 0.25 & Prot $\%$ \\
\hline 8 & 1 & & $4.97 \times 10^{-5}$ & ARS-BFGL-NGS-63329 & $113,252,230$ & 0.01 & $\mathrm{pH}$ \\
\hline $9 \mathrm{a}$ & 1 & & $1.51 \times 10^{-5}$ & Нарmap53034-rs29011422 & $69,696,334$ & 0.34 & Prot $\%$ \\
\hline $9 \mathrm{~b}$ & 1 & & $7.38 \times 10^{-6}$ & ARS-BFGL-NGS-88859 & $83,575,446$ & 0.38 & Prot $\%$ \\
\hline 11 & $6(10)$ & $85,936-88,029$ & $\left(4.43 \times 10^{-5}, 4.5 \times 10^{-6}\right)$ & ARS-BFGL-NGS-119913 & $86,779,385$ & 0.50 & $\mathbf{t}_{\max }, \mathrm{RCT}_{\mathrm{eq}}$ \\
\hline 13 & 1 & & $3.74 \times 10^{-5}$ & BTB-00531553 & $57,198,685$ & 0.05 & $\mathrm{k}_{20}$ \\
\hline $15 \mathrm{a}$ & 2 & $14,243-14,272$ & $\left(7.29 \times 10^{-6}, 7.24 \times 10^{-6}\right)$ & ARS-BFGL-NGS-114291 & $14,242,668$ & 0.01 & $\mathrm{RCT}$ \\
\hline $15 \mathrm{~b}$ & 1 & & $1.08 \times 10^{-5}$ & ARS-BFGL-NGS-68607 & $55,488,319$ & 0.01 & $\mathrm{RCT}$ \\
\hline 19 & 2 & $2,094-2,271$ & $\left(3.47 \times 10^{-5}, 2.96 \times 10^{-5}\right)$ & Нарmap39832-BTA-46468 & $2,093,500$ & 0.32 & $\mathrm{a}_{30}$ \\
\hline 20 & 1 & & $3.72 \times 10^{-5}$ & ARS-BFGL-NGS-1751 & $17,412,441$ & 0.17 & Prot $\%$ \\
\hline $23 \mathrm{a}$ & 1 & & $2.85 \times 10^{-5}$ & Hapmap38418-BTA-57213 & $8,819,178$ & 0.11 & $\mathrm{k}_{\mathrm{SR}}$ \\
\hline $23 \mathrm{~b}$ & 1 & & $2.59 \times 10^{-6}$ & ARS-BFGL-NGS-99929 & $10,631,079$ & 0.07 & $\mathrm{k}_{\mathrm{SR}}$ \\
\hline 26 & 1 & & $2.5 \times 10^{-5}$ & ARS-BFGL-NGS-23064 & $20,365,711$ & 0.47 & $\mathrm{k}_{\mathrm{CF}}$ \\
\hline $28 \mathrm{a}$ & 1 & & $2.71 \times 10^{-5}$ & ARS-BFGL-NGS-115508 & $33,729,338$ & 0.11 & $\mathrm{t}_{\max }$ \\
\hline $28 \mathrm{~b}$ & 1 & & $3.09 \times 10^{-5}$ & Нарmap48306-BTA-36540 & $38,449,335$ & 0.13 & Prot $\%$ \\
\hline
\end{tabular}

${ }^{1} \mathrm{BTA}=$ Bos taurus autosome chromosome; SNP (signals) = number of the single nucleotide polymorphisms significantly associated with the trait, the total number of significant signals per each genomic region is in parentheses; Interval = region on the chromosome spanned among the significant SNP (in base pairs); $P$-value (range) $=P$-value of the highest significant SNP adjusted for genomic control and the range of the $P$-values when multiple SNP were significantly associated with one trait; Top SNP location (bp) $=$ position of the highest significant SNP on the chromosome in base pairs on UMD3.1 (http://www.ensembl.org/index.html); Top SNP MAF = minor allele frequency of the top SNP.

预 $\quad{ }^{2} \mathrm{RCT}=$ rennet coagulation time ( $\mathrm{min}$ ) of samples coagulating within $45 \mathrm{~min}$ from enzyme addition; $\mathrm{k}_{20}=$ curd-firming time (min) of samples reaching $20 \mathrm{~mm}$ of firmness within 45 o min from enzyme addition; $\mathrm{a}_{30}=$ curd firmness $(\mathrm{mm})$ at $30 \mathrm{~min}$ after enzyme addition; Prot $\%=$ protein percent; $\mathrm{RCT}_{\mathrm{eq}}=\mathrm{rennet}_{\mathrm{c}} \mathrm{coagulation}$ time (min) estimated using the $\mathrm{CF}_{1}$ $\rightarrow$ equation; $\mathrm{CF}_{\mathrm{P}}=$ potential asymptotical curd firmness $(\mathrm{mm}) ; \mathrm{k}_{\mathrm{CF}}=$ curd-firming rate constant $(\% / \min ) ; \mathrm{k}_{\mathrm{SR}}=$ syneresis rate constant $(\% /$ min $) ; \mathrm{CF}_{\max }=$ maximum curd firmness D. $(\mathrm{mm}) ; \mathrm{t}_{\max }=$ time to $\mathrm{CF}_{\max }(\min )$. The trait with the highest $P$-value in each genomic region is bolded. 
of a different QTL. Trans-2,3-enoyl-CoA reductaselike (TECRL; $\sim 81.5-81.6 \mathrm{Mbp}$ ) is located in the first area and is involved in lipid metabolic process. In the second region, $G C(88.69-88.74 \mathrm{Mbp})$ is mapped. The protein encoded by $G C$ belongs to the general albumin family, it is a vitamin D-binding protein, and regulates vitamin transportation to target tissues and vitamin $\mathrm{D}$ metabolism. Moreover, it is involved in the metabolism of lipids and lipoproteins.

\section{BTA11}

Chromosome 11 was the second most frequently identified chromosome in the GWAS analysis where significant associations with $\mathrm{RCT}_{\mathrm{eq}}$ and $\mathrm{t}_{\max }$ were detected at around $87 \mathrm{Mbp}$. In previous studies, QTL on BTA11 related to $\alpha-, \beta$-, and $\kappa-\mathrm{CN}$ as well as $\alpha-\mathrm{LA}$ and $\beta-\mathrm{LG}$ concentrations have been reported (Heck et al., 2009; Berry et al., 2010; Bonfatti et al., 2010), suggesting $P A E P$ (also known as $L G B$ ) located at $103.3 \mathrm{Mbp}$ as a candidate gene; also, association between RCT and $L G B$ has been shown (Bonfatti et al., 2010; Cecchinato et al., 2012b). Moreover, the tail of BTA11 ( 107 Mbp) has been linked with high peaks to percentages of $\alpha-$, $\beta$-, and $\kappa-\mathrm{CN}, \beta-\mathrm{LG}$, and casein index (Schopen et al., 2011). None of those signals was confirmed in our study. Therefore, our signal at $87 \mathrm{Mbp}$ indicates a potential new QTL. A variety of protein codings are mapped in the identified in our study region between 85.9 and 88 Mbp. In this area LPIN 1 ( $\sim 86.0-86.1 \mathrm{Mbp})$, GRHL1 ( 87.5-87.6 Mbp), and IAH1 ( 87.94-87.95 Mbp) are present. Each of these 3 genes are involved in lipid metabolic process. Associations of LPIN 1 with $\mathrm{k}_{20}$ and $\mathrm{a}_{30}$ have been previously reported (Cecchinato et al., 2012a). Close to this region ( $\sim 88.58 \mathrm{Mbp})$, the DNAbinding protein inhibitor ID2 is mapped, which is involved in the mammary gland epithelium development. In addition, marker ARS-BFGL-NGS-37074 (88,028,793 bp) is located within the ASAP2 ( 88.01-88.18 Mbp); this marker was significant, albeit at a weak strength.

\section{Signals on Chromosomes Other than BTA6 and BTA11}

Significant associations in 10 more chromosomes were detected in our study. Apart from BTA6, 6 more chromosomes are in common between our study and Gregersen et al. (2015), namely BTA1, 9, 13, 15, 16, and 23. However, signals were identified in different genomic regions. For example, on BTA1 a signal at 9.5 $\mathrm{Mbp}$ was found for $\mathrm{RCT}_{\text {eq }}$, whereas in the conditional analysis $\mathrm{a}_{30}$ was associated with BTA1 at $29.7 \mathrm{Mbp}$. In Gregersen et al. (2015), a QTL interval at 70.7 to $80 \mathrm{Mbp}$ on BTA1 is reported. On BTA15, our analysis identified 2 regions related to $\mathrm{RCT}$ at 14.2 and 55.5 Mbp which are quite far apart from the locations reported in Gregersen et al. (2015; 37-44 and 61-62 Mbp, respectively). On BTA13, a significant SNP $(P$-value $=$ $1.45 \times 10^{-5}$ ) was detected at $47.9 \mathrm{Mbp}$, whereas a signal at $58 \mathrm{Mbp}$ was reported in Gregersen et al. (2015). Note, however, that in the conditional analysis a signal at $57 \mathrm{Mbp}$ was observed for $\mathrm{k}_{20}$. These differences might not be surprising, as the traits analyzed in the 2 studies (with the exception of RCT), although all related to coagulation properties of the milk, are different.

Peaks on BTA2, 18, and 24 have also been reported in a previous study (Tyrisevä et al., 2008). No signal was found on those chromosomes in our analysis. However, in Tyrisevä et al. (2008) the traits analyzed were coagulation versus noncoagulation, a selective DNA pooling using microsatellite markers was used, and the analysis was carried out in a Finnish Ayrshire dairy cattle population. Moreover, the chromosomes in Tyrisevä et al. (2008) have been also reported in Gregersen et al. (2015), but the positions of the signals do not match.

A possible consideration could be why DGAT1, located on BTA14 and related to milk fat percentage, was not identified in our study. This was not surprising, as DGAT1 in Italian Brown Swiss population is not segregating.

\section{GWAS Results and Genetic Correlations Among Traits}

In the present study we found traits with high genetic correlations $\left(\mathrm{r}_{\mathrm{g}}>|0.07|\right)$ showing different genomic signals. For example, RCT and $\mathrm{a}_{30}$ had a genetic correlation of -0.88 (Supplementary Table S1; http://dx.doi. org/10.3168/jds.2015-10078). Both traits showed a signal on BTA6 sharing 6 significant SNP in common. However, RCT was also associated with BTA13 and 15, whereas $\mathrm{a}_{30}$ was linked to BTA19. Another example is between $\mathrm{RCT}_{\mathrm{eq}}$ and $\mathrm{t}_{\max }$, which are strongly genetically correlated $\left(r_{g}=0.87\right)$. Three significant SNP were in common ( 1 on BTA6 and 2 on BTA11), but $\mathrm{RCT}_{\text {eq }}$ was also associated with BTA1 whereas $\mathrm{t}_{\max }$ was associated with BTA28. In addition, $\mathrm{RCT}_{\text {eq }}$ and $\mathrm{CF}_{\mathrm{P},} \mathrm{CF}_{\mathrm{P}}$ and $\mathrm{k}_{\mathrm{SR}}$, and $\mathrm{CF}_{\max }$ and $\mathrm{k}_{\mathrm{SR}}$ had no common significant $\mathrm{SNP}$ but are strongly genetically related $\left(\mathrm{r}_{\mathrm{g}}\right.$ of $0.7,-0.79$, and -0.74 , respectively). These results could be dually interpreted. Thus, perhaps, the different genomic regions identified on highly genetically correlated traits could be attributed to the noncorrelated part between the traits. Conversely, it could also be claimed that the information of genetic correlation between related traits involved in the same biological process might be an extra hint on distinguishing false positives as well 
as supporting evidence of true signals. In any case, an extra benefit can be gained by taking into account the genetic correlations among phenotypes describing the same process in GWAS studies, resulting in a more holistic view of the complex trait under study.

\section{Partitioning a Complex Phenotype into Different Components}

In the genome-wide associations performed in our study, the phenotypes used were either 3 single-point measurements that are traditionally used in dairy industry or were obtained after allowing an extended coagulation period (Bittante et al., 2013). Between the 2 groups of phenotypes, only BTA6 was common. However, for both sets, marker Hapmap52348-rs29024684 was identified as the most significant. The $\mathrm{CF}_{\mathrm{t}}$ traits strengthened the evidence of the obtained signals for MCP traits on BTA6, and also pinpointed genomic regions not captured by the $\mathrm{MCP}$, for instance on BTA11. Therefore, evidence exists that by partitioning the traits into different (potentially correlated) components or phenotypes, more information might be extracted concerning the underlying genetic mechanism regulating the traits. The importance of phenomics and phenotype definition has been recently emphasized as an essential part of information for the better understanding of the genomic regulation of traits (Houle et al., 2010).

\section{Breeding}

The clear peaks on BTA6 together with the identification of Hapmap52348-rs29024684 (closely located to CSN3) as highly significant in multiple traits indicate that, perhaps, more emphasis should be given for selection on this marker (or directly to CSN3). The minor allele frequency of the marker in this data set was 0.23 . Moreover, depending upon the trait, the proportion of phenotypic variance captured by this marker ranged between 40 (for $\mathrm{k}_{20}$ ) and $2 \%$ (for $\mathrm{a}_{30}$ ) (Supplementary Table S3; http://dx.doi.org/10.3168/jds.2015-10078). The same marker has been significantly associated in a recent preliminary GWAS analysis, in the same population, with the recoveries of the milk fat into the cheese, explaining a large proportion of the phenotypic and genetic variability (Dadousis et al., 2015). This provides extra support for the significance of this genomic region for cheese-related properties of milk. Therefore, our results show that selection of this marker is possible for the Italian Brown Swiss population.

With the exception of region $6 \mathrm{~d}$, the rest of the associations identified were mild to weak. This can be partly attributed to the limited sample size. As direct
MCP measurements are costly and time consuming, a much larger sample size seems not feasible. An alternative for increasing the power of GWAS could be to use $\mathrm{MCP}$ and $\mathrm{CF}_{\mathrm{t}}$ traits predicted by Fourier transform infrared spectroscopy (Ferragina et al., 2015), which could be easily applied at population level (Cecchinato et al., 2015a).

\section{CONCLUSIONS}

Eleven traits related to MCP and $\mathrm{CF}$ were used in GWAS. Even taking into account the limitations imposed by the sample size and the number of SNP analyzed, the results confirmed the importance of the casein cluster on BTA6 and more precisely of CSN3, whereas potential new QTL appeared at 82.6 and 88.4 Mbp on the same chromosome. Evidence of a QTL on BTA11 at $\sim 87 \mathrm{Mbp}$ has been found. Moreover, new signals along the genome have been detected. However, these genomic regions should be reproduced in future studies, ideally on a larger scale. To the best of our knowledge, this is the largest GWAS study carried out with MCP. The new set of 7 traits describing the whole process of milk coagulation to syneresis strengthened the support of QTL on BTA6. Moreover, the $\mathrm{CF}_{\mathrm{t}}$ traits showed signals on genomic regions not related to the traditionally measured MCP traits. Results indicate the importance of phenotypic integration in GWAS studies for a better connection between phenome and the genome. Replication of the GWAS results from independent, and ideally of large scale, studies remains crucial. This will also help to clarify the picture of the weak signals detected in our study.

\section{ACKNOWLEDGMENTS}

We thank the Trento Province (Italy), the Italian Brown Swiss Cattle Breeders Association (ANARB, Verona, Italy), and the Superbrown Consortium of Bolzano and Trento (Italy) for financial and technical support. C. Dadousis benefitted from financial support of the CARIPARO (Cassa di Risparmio di Padova e Rovigo) Foundation (Padua, Italy).

\section{REFERENCES}

Amin, N., C. M. Van Duijn, and Y. S. Aulchenko. 2007. A genomic background based method for association analysis in related individuals. PLoS ONE 2:e1274.

Berry, S. D., N. Lopez-Villalobos, E. M. Beattie, S. R. Davis, L. F. Adams, N. L. Thomas, A. Ankersmit-Udy, A. M. Stanfield, K. Lehnert, H. E. Ward, J. A. Arias, R. J. Spelman, and R. G. Snell. 2010. Mapping a quantitative trait locus for the concentration of beta-lactoglobulin in milk, and the effect of beta-lactoglobulin genetic variants on the composition of milk from Holstein-Friesian $\mathrm{x}$ jersey crossbred cows. N. Z. Vet. J. 58:1-5. 
Bittante, G. 2011. Modeling rennet coagulation time and curd firmness of milk. J. Dairy Sci. 94:5821-5832.

Bittante, G., B. Contiero, and A. Cecchinato. 2013. Prolonged observation and modelling of milk coagulation, curd firming, and syneresis. Int. Dairy J. 29:115-123.

Bittante, G., M. Penasa, and A. Cecchinato. 2012. Invited review: Genetics and modeling of milk coagulation properties. J. Dairy Sci. 95:6843-6870.

Bonfatti, V., G. Di Martino, A. Cecchinato, L. Degano, and P. Carnier. 2010. Effects of $\beta$-к-casein (CSN2-CSN3) haplotypes, $\beta$-lactoglobulin (BLG) genotypes, and detailed protein composition on coagulation properties of individual milk of Simmental cows. J. Dairy Sci. 93:3809-3817.

Caroli, A. M., S. Chessa, and G. J. Erhardt. 2009. Invited review: Milk protein polymorphisms in cattle: Effect on animal breeding and human nutrition. J. Dairy Sci. 92:5335-5352.

Cecchinato, A., A. Albera, C. Cipolat-Gotet, A. Ferragina, and G. Bittante. 2015a. Genetic parameters of cheese yield and curd nutrient recovery or whey loss traits predicted using Fourier-transform infrared spectroscopy of samples collected during milk recording on Holstein, Brown Swiss, and Simmental dairy cows. J. Dairy Sci. 98:4914-4927.

Cecchinato, A., S. Chessa, C. Ribeca, C. Cipolat-Gotet, T. Bobbo, J. Casellas, and G. Bittante. 2015b. Genetic variation and effects of candidate-gene polymorphisms on coagulation properties, curd firmness modeling and acidity in milk from Brown Swiss cows. Animal 9:1104-1112.

Cecchinato, A., C. Cipolat-Gotet, J. Casellas, M. Penasa, A. Rossoni, and G. Bittante. 2013. Genetic analysis of rennet coagulation time, curd-firming rate, and curd firmness assessed over an extended testing period using mechanical and near-infrared instruments. J. Dairy Sci. 96:50-62.

Cecchinato, A., C. Ribeca, A. Maurmayr, M. Penasa, M. De Marchi, N. P. P. Macciotta, M. Mele, P. Secchiari, G. Pagnacco, and G. Bittante. 2012b. Short communication: Effects of $\beta$-lactoglobulin, stearoyl-coenzyme A desaturase 1, and sterol regulatory element binding protein gene allelic variants on milk production, composition, acidity, and coagulation properties of Brown Swiss cows. J. Dairy Sci. 95:450-454.

Cecchinato, A., C. Ribeca, M. Penasa, C. Cipolat Gotet, M. De Marchi, A. Maurmayr, and G. Bittante. 2012a. Associations between single nucleotide polymorphisms in multiple candidate genes on milk yield, composition, coagulation properties and individual cheese yield in Brown Swiss cows. J. Dairy Sci. 95(Suppl. 2):402. (Abstr.)

Chessa, S., O. Bulgari, R. Rizzi, L. Calamari, P. Bani, S. Biffani, and A. M. Caroli. 2014. Selection for milk coagulation properties predicted by Fourier transform infrared spectroscopy in the Italian Holstein-Friesian breed. J. Dairy Sci. 97:4512-4521.

Cipolat-Gotet, C., A. Cecchinato, M. De Marchi, M. Penasa, and G. Bittante. 2012. Comparison between mechanical and near-infrared methods for assessing coagulation properties of bovine milk. J. Dairy Sci. 95:6806-6819.

Dadousis, C., C. Cipolat-Gotet, S. Biffani, E. L. Nicolazzi, G. J. M. Rosa, D. Gianola, G. Bittante, and A. Cecchinato. 2015. Genomewide association study for cheese yield and curd nutrients recovery in bovine milk. Page 358 in Book of Abstracts of the 66th Annual Meeting of the European Federation of Animal Science, Warsaw, Poland. Wageningen Academic Publishers, Wageningen, the Netherlands.

Ferragina, A., G. de los Campos, A. I. Vazquez, A. Cecchinato, and G. Bittante. 2015. Bayesian regression models outperform partial least squares methods for predicting milk components and technological properties using infrared spectral data. J. Dairy Sci 98:8133-8151.

GenABEL Project Developers. 2013. GenABEL: Genome-wide SNP association analysis. $\mathrm{R}$ package version $1.8-0$. http://CRAN.Rproject.org/package $=$ GenABEL

Gengler, N., G. R. Wiggans, J. R. Wright, H. D. Norman, and C. W Wolfe. 1997. Application of canonical transformation with missing values to multitrait evaluation of Jersey type. J. Dairy Sci 80:2563-2571.

Glantz, M., H. Lindmark Månsson, M. Paulsson, and H. Stålhammar. 2012. Genomic selection in relation to bovine milk composition and processability. J. Dairy Res. 79:53-59.

Glantz, M., H. Lindmark Månsson, H. Stålhammar, and M. Paulsson. 2011. Effect of polymorphisms in the leptin, leptin receptor, and acyl-coenzyme A:diacylglycerol acyltransferase 1 (DGAT1) genes and genetic polymorphism of milk proteins on cheese characteristics. J. Dairy Sci. 94:3295-3304.

Gregersen, V. R., F. Gustavsson, M. Glantz, O. F. Christensen, H. Stålhammar, A. Andrén, H. Lindmark-Månsson, N. A. Poulsen, L. B. Larsen, and M. Paulsson. 2015. Bovine chromosomal regions affecting rheological traits in rennet-induced skim milk gels. J. Dairy Sci. 98:1261-1272.

Heck, J. M. L., A. Schennink, H. J. F. van Valenberg, H. Bovenhuis, M. H. P. W. Visker, J. A. M. van Arendonk, and A. C. M. van Hooijdonk. 2009. Effects of milk protein variants on the protein composition of bovine milk. J. Dairy Sci. 92:1192-1202.

Houle, D., D. R. Govindaraju, and S. Omholt. 2010. Phenomics: The next challenge. Nat. Rev. Genet. 11:855-866.

Ikonen, T., K. Ahlfors, R. Kempe, M. Ojala, and O. Ruottinen. 1999 Genetic parameters for the milk coagulation properties and prevalence of noncoagulating milk in Finnish dairy cows. J. Dairy Sci. $82: 205-214$

Misztal, I., S. Tsuruta, T. Strabel, B. Auvray, T. Druet, and D. Lee. 2002. BLUPF90 and related programs (BGF90). Proc. 7th World Congress on Genetics Applied to Livestock Production, Montpellier, France. Commun. No. 28-07.

Mrode, R. A. 2005. Linear Models for the Prediction of Animal Breeding Values. 2nd ed.

R Core Team. 2013. R: A language and environment for statistical computing. Version 3.0.2. http://www.R-project.org/.

Schopen, G. C. B., M. H. P. W. Visker, P. D. Koks, E. Mullaart, J. A. M. van Arendonk, and H. Bovenhuis. 2011. Whole-genome association study for milk protein composition in dairy cattle. J. Dairy Sci. 94:3148-3158.

Svishcheva, G. R., T. I. Axenovich, N. M. Belonogova, C. M. van Duijn, and Y. S. Aulchenko. 2012. Rapid variance componentsbased method for whole-genome association analysis. Nat. Genet. 44:1166-1170.

Turner, S. D. 2014. qqman: An R package for visualizing GWAS results using Q-Q and Manhattan plots. bioRxiv. http://dx.doi. org $/ 10.1101 / 005165$.

Tyrisevä, A. M., K. Elo, A. Kuusipuro, V. Vilva, I. Jänönen, H. Karjalainen, T. Ikonen, and M. Ojala. 2008. Chromosomal regions underlying noncoagulation of milk in Finnish Ayrshire cows. Genetics 180:1211-1220.

Van Eenennaam, A. L., K. A. Weigel, A. E. Young, M. A. Cleveland, and J. C. Dekkers. 2014. Applied animal genomics: Results from the field. Annu. Rev. Anim. Biosci. 2:105-139.

Walstra, P., P. Walstra, J. T. Wouters, and T. J. Geurts. 2014. Dairy Science and Technology. CRC Press, Boca Raton, FL.

The Wellcome Trust Case Control Consortium. 2007. Genome-wide association study of 14,000 cases of seven common diseases and 3,000 shared controls. Nature 447:661-678. 